\title{
Locally Advanced Prostate Neuroendocrine Carcinoma
}

National Cancer Institute

\section{Source}

National Cancer Institute. Locally Advanced Prostate Neuroendocrine Carcinoma. NCI

Thesaurus. Code C158914.

A prostate neuroendocrine carcinoma that has spread from its original site of growth to nearby tissues or lymph nodes. 